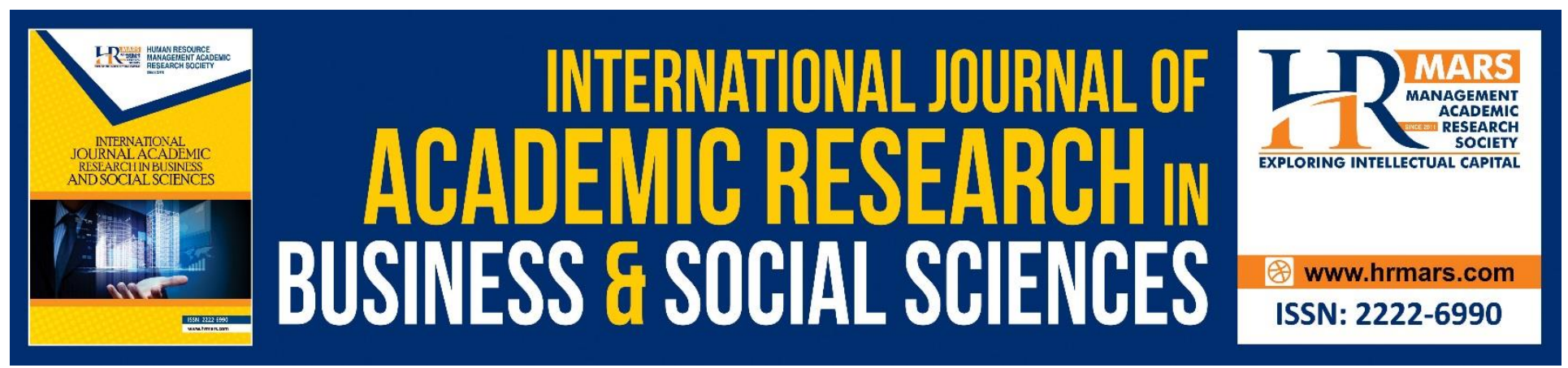

\title{
Ethics and Value Theory in Islamic Science's Philosophy
}

\section{Shahirah Said \& Mohd Shukri Hanapi}

To Link this Article: http://dx.doi.org/10.6007/IJARBSS/v9-i3/5718

DOI: $\quad 10.6007 /$ IJARBSS/v9-i3/5718

Received: 17 Feb 2019, Revised: 23 March 2019, Accepted: 06 April 2019

Published Online: 13 April 2019

In-Text Citation: (Said \& Hanapi, 2019)

To Cite this Article: Said, S., \& Hanapi, M. S. (2019). Ethics and Value Theory in Islamic Science's Philosophy. International Journal of Academic Research in Business and Social Sciences, 9(3), 572-577.

\section{Copyright: (C) 2019 The Author(s)}

Published by Human Resource Management Academic Research Society (www.hrmars.com)

This article is published under the Creative Commons Attribution (CC BY 4.0) license. Anyone may reproduce, distribute, translate and create derivative works of this article (for both commercial and non-commercial purposes), subject to full attribution to the original publication and authors. The full terms of this license may be seen

at: http://creativecommons.org/licences/by/4.0/legalcode

Vol. 9, No. 3, 2019, Pg. 572 - 577

Full Terms \& Conditions of access and use can be found at http://hrmars.com/index.php/pages/detail/publication-ethics 


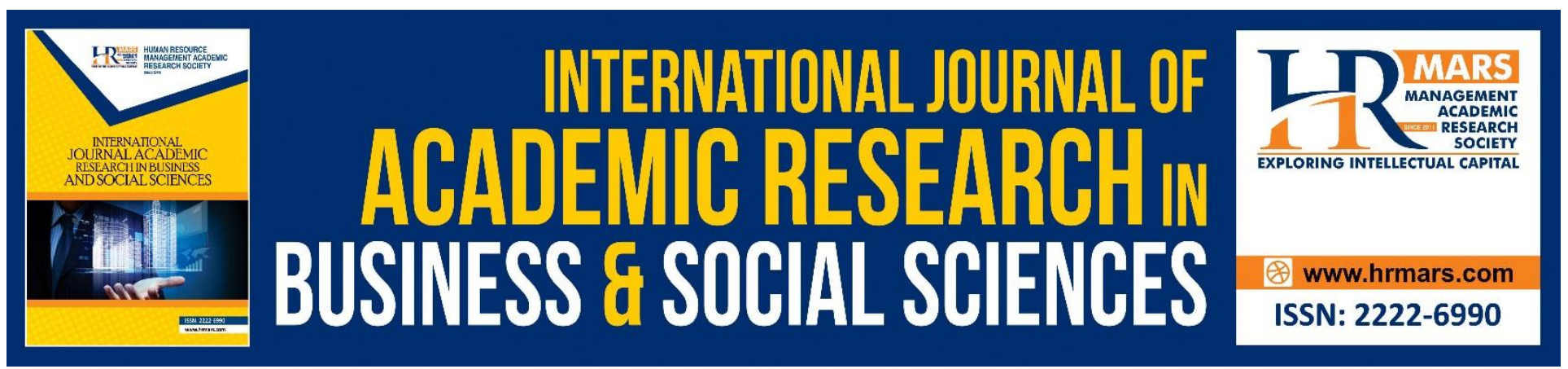

\title{
Ethics and Value Theory in Islamic Science's Philosophy
}

\author{
Shahirah Said \& Mohd Shukri Hanapi \\ ${ }^{1,2}$ Centre for Islamic Development Management Sudies (ISDEV), \\ University Sains Malaysia, 11800 Minden, Penang, Malaysia
}

\begin{abstract}
The government of Abbassiyyah was memorable in history as it successfully brings to excellence Islamic civilization, during the ruling of Caliph Harun al- Rasyid and his son, al-Ma'mum. In that era, philosophy and science play a substantial role holistically under the framework of Islam. However, after that science activities were given less attention and further deteriorated. Among the factors that contribute to this are political instability, the lack of support from the government on science activities and others. That said, the science progress has not been impeded by religious activities or Islam in particular. The progress even exists to this very day. The Islamic science philosophy continues to be the focal point by its thinkers as a way to place Islamic science philosophy in its rightful place. Thus, this working paper carries two objectives. First of all, it seeks to identify the definition of philosophy of Islamic science and secondly, it intends to analyse the contemporary philosophical of Islamic science study trend. This library study reveals that the definition of philosophy Islamic science is more comprehensive than the modern counterpart. Apart from that, the discussion on it covers three substantial aspects-tawheed, al-Qur'an as main source, and ethics and value. All of these carry the purpose of ensuring that the philosophy of Islamic science stays relevant from time to time.
\end{abstract}

Keywords: Ethic, Value, Theory and Islamic Science

\section{Introduction}

Looking back into the historical stance of the development of philosophy of science, there was no doubt that the philosophy of science began to spread in the Middle East not West. There is evidence that in Egypt there are the Nile River valley and in Babylon (Mesopotamia). This is due to the fact they are located in the Tigris and Euphrates rivers. Both these rivers were regarded as the pioneer of ancient civilization as they contained a wealth of knowledge and science and technological advancement that had yet to exist anywhere else (Abdullah, 2010). According to Nasr (1986), when Islam had reached its peak with its science philosophies, the West had undergone the 'dark' phase following the influence of religion from church institutions in 400-1100 AD. This was 
the lowest point of science advancement in the Western part of Europe. In the 12th century AD, Islamic civilization had dominated the civilizations in the African, Asian and Andalusian worlds (Spain and Portugal) that were under the ruling of Muslim caliphs (Zain et. al, 1985). The success of the Islamic government at that time was closely linked to the three things that were to adhere to tawheed, wahyu as the main source and noble ethics of man in developing the philosophy of Islamic science. Thus, this library study carries two objectives. The first is to identify the definition of philosophy of Islamic science and the second one is to analyse the study trend of ethics and value theory in philosophical of Islamic science. To fulfil the two objectives, the paper is divided into three aspects, namely philosophy of Islamic science interpretation, its study analysis and the overall conclusion.

\section{The Philosophy of Islamic Science}

To facilitate the discussion in this section, the writers divide the discussion into two, the definition of philosophy and the definition of Islamic science. At the end of this section, we will state the definitions that will be used in this paper.

Universally, philosophy is frequently associated with knowledge that emphasises conceptual rather than factual aspects. Concept refers to an idea that involves understanding, whereas facts refer more to the truth about something that results from an observation. Facts are exposed to a situation that could be accurate or true today but inaccurate tomorrow, such as historical facts, scientific facts etc. (Long, 2008). Ismail (2006) stated that philosophy, in general, means the love for knowledge, truth, morality and a metaphysical system processed through an intellectually mature mind. The philosophy used in this study refers to a type of knowledge that explains the truth about knowledge based on the al-Qur'an and Sunnah (Jusoh \& Muhammad (2007). Philosophy also involves activities that require thinking with a rational mind and the capability to explore and understand various fields of knowledge as well as the whole realm of nature on this earth created by Allah SWT. However, the ability to think cannot surpass the reality of tawheed of Allah SWT (Nasr, 2008).

Science, from an Islamic paradigm, refers to a process that explains nature by using specific methods that are scientific in nature but does not overstep the reality of tawheed of Allah SWT (Othman, 1996). According to Sardar (1992) and Nasr (2008), Islamic science comprises specific activities that seek the truth and solve problems. All these must operate within the structure of Islamic values. This means that objectives, tools, methods and processes should be Islamic-based. Hence, science is one of those tools used to appreciate the prowess of God but God cannot be explained by using science (Akdogan, 2008; Awang, 2003). Science, according to Othman (1996), Sardar (1992) and Nasr (2008), is more suitable and proper when used in this working paper. Science is a process that explains the phenomena of nature by using specific methods that are scientific in nature but based on the tawheed of Allah SWT. All these methods have to operate within the structure of Islamic values itself. This means that all tools, methods and processes should be fully based on Islam. The main aim of Islamic-based science is to seek well-being for humans in this world as well as the blessing of Allah SWT in the after-world. 


\section{The Study of Ethics and Value Theory in Philosophy of Islamic Science}

Theory of ethics and values in the Philosophy of Islamic science is normally a study that discusses things that will give benefit or otherwise, whether materially or spiritually, and so on. Conclusively, the theory of values is characteristically objective or subjective (Abdullah, 2010). The discussion of the theory of value and ethics in the research method can be found in the study done by Isa (2009 \& 2013). According to the study, to ensure that the biotechnology field research is at par with the current fiqh, bioethics is given due attention so that it can resolve ethical issues in science and technology advancement. This is different from the study done by Mastor (2009) that centers more on the ethics of the Muslim scientists themselves. Following the study, Muslim scientists have to bear two responsibilities which are those responsible in fulfilling their duties towards Allah SWT and secondly, serving the people for their benefits.

Next, the work by Alias (2016) with regard to free values in scientific studies, especially in research that is Islamic-oriented. The issues in scientific research have also attracted other scholars, as there were several issues that emerge in the philosophy or application in either research or study. For instance, the work by Adebayo (2015); Shaikh Mohd Salleh and Baharuddin (2007) also Badrussyamsi (2015) elaborated on the importance of Islamizing science and its impact on the greatness of Islamic science. This is vital to prevent it from being influenced by modern science. Meanwhile, the work by Badrussyamsi (2015) is slightly different where it only established the importance of spiritual and theology on the scientific aspects of Islam in general.

Meanwhile, a study was done by Amir (2016) with regard to the analysis towards tafsir alSya'rawi composed by Muhammad Mutawalli al-Sya'rawi who is one of the Islamic science thinkers. Following the study, the concept of scientific elements in the al-Qur'an encompasses three main parts which are Divine Science, Social Science and Natural Science. Apart from that, al-Sya'rawi was also consistent in using the method of al-'Ilmi al-Naqli al-litima' $i$ in the interpretation of scientific verses. Meanwhile, Azhar and Rahim (2010) gave their contribution of study towards the integration of scientific thinking and shari'a study especially in Malaysia. According to the study, there is a need to apply the element of scientific thinking in the current shari'a study as it is an urgent requirement in this era of globalisation. Therefore, the concern of the Muslim fuqaha' to offer solutions in addressing Islamic issues is very timely.

\section{Conclusion}

Based on the observation on previous studies, there are three things that are often discussed. The first is on how the contribution of ideas and thoughts of these prominent figures is able to place the Philosophy of Islamic Science back in its place. Secondly, the effort to combine Islam and science; and thirdly, the prominence of al-Qur'an also can be proven through scientific discoveries, as well as explaining the difference in the theory of values and morals in the philosophy of Islamic science. All the elements contribute to the development of civilization, at the same time, signifying the achievement of Philosophy of Islamic Science that drives humans towards nobility. 
INTERNATIONAL JOURNAL OF ACADEMIC RESEARCH IN BUSINESS AND SOCIAL SCIENCES

Vol. 9, No. 3, March, 2019, E-ISSN: 222 2-6990 @ 2019 HRMARS

\section{Acknowledgement}

This paper is part of the research findings entitled The Development of Wasatiyyah-Based Consumerism (203.CISDEV 6711588), which was financed by the Fundamental Research Grant Scheme (FRGS) Phase 1/2017. Special appreciation is owed to Ministry of Higher Education Malaysia (MOHE) and Universiti Sains Malaysia (USM) for sponsoring and supporting this research.

\section{Corresponding Author}

Email: shahirahsaid@gmail.com (Shahirah Said)

\section{References}

Abdullah, A.R. (2010). Wacana falsafah sains sejarah dan pemikiran. Pulau Pinang: Pusat Kajian Pengurusan Pembangunan Islam (ISDEV), USM

Adebayo, R.I. (2015). From Islamicizing the sciences to strategizing for Muslims' scientific breakthrough. International Journal of Islamic Thought. Vol. 7. Jun. 25-38

Akdogan, C. (2008). Sains dalam Islam dan Barat. In. Baharudin Ahmad. Falsafah sains dari perspektif Islam. Kuala Lumpur: Dewan Bahasa dan Pustaka.

Alias, M.S. (2014). Konsep saintifik dalam kaedah penyelidikan berteraskan Islam: analisis pemikiran Ibn Al-Haytham. Disertasi sarjana yang tidak diterbitkan. Pusat Kajian Pengurusan Pembangunan Islam (ISDEV), USM.

Alias, M.S. (2016). Bebas nilai dalam penyelidikan saintifik: Kajian dari perspektif perkaedahan penyelidikan berteraskan Islam. Tesis doktor falsafah yang tidak diterbitkan. Pusat Kajian Pengurusan Pembangunan Islam (ISDEV) Universiti Sains Malaysia

Amir, S. (2016). Elemen saintifik dalam Al-Qur'an: Analisis terhadap Tafsir Al-Sha'Rawi Karangan Muhammad Mutawalli Al-Sha'Rawi (Tesis doktor falsafah yang tidak diterbitkan). Akademi Pengajian Islam, Universiti Malaya

Awang, R. (2003). Falsafah sains dan pembangunan ke arah dimensi baru. Skudai: Penerbit Universiti Teknologi Malaysia

Azhar, A. \& Abdul Rahim, R.A. (2010). Aplikasi elemen pemikiran saintifik dalam pengajian syariah. Journal of Fiqh, No. 7. pp 1-28

Badrussyamni. (2015). Spiritualitas sains dalam Islam: Mengungkap teologi saintifik islam. MIQOT. Vol. XXXIX No. 2 Julai-Disember. pp. 255-275

Baharuddin, A. (2007). Pendekatan holistik agama dan sains: mekanisme dan penghayatan penyelesaian alternatif. in. Syed Muhammad Dawilah al-Edrus (ed). Pendekatan holistik sains dan agama cabaran ketamadunan. Kuala Lumpur: Dewan Bahasa dan Pustaka.

Isa, N.M. (2009). Bioetika dan figh sains dan teknologi: sama tapi tak serupa?. Kertas kerja yang dibentangkan di Simposium Kebangsaan Fiqh Sains dan Teknologi. Anjuran Universiti Teknologi Malaysia.

Isa, N.M. (2013). Etika dalam Bioteknologi moden: Kajian ke atas respons para ilmuan Islam terpilih mengenai garis panduan etika Islam. Tesis doktor falsafah yang tidak diterbitkan. Jabatan Pengajian Sains Dan Teknologi Fakulti Sains Universiti Malaya

Ismail, M.R. (2006). Falsafah sains pendekatan kualitatif. Kuala Lumpur: Dewan Bahasa dan Pustaka. 
Jusoh, Y. \& Muhammad, A. (2007). Pendidikan falsafah sains al-Qur'an. Skudai: Universiti Teknologi Malaysia.

Khairuldin, W.M.K.F.W., Embong, A.H., Anas, W.N.I.W.N., Mohd, H. \& Ismail, D. (2018), The Application of Technology in the Dissemination of Fatwas: A Study on Religious Institutions in Malaysia, International Journal of Civil Engineering and Technology, 9(7), 2018, pp. 15901596.

Khairuldin, W.M.K.F.W., Ismail, D., Anas, W.N.I.W.N., Ibrahim, I., \& Fauzi, N. (2016). Freedom of Speeches by Mufti According to Islam: Implication to Fatwa in Malaysia. International Journal of Academic Research in Business and Social Sciences. 6 (12). Pp 141-151.

Khairuldin, W.M. K. F. W. (2018). Fatwa Role in Education and Legal Dispute in Malaysia. International Journal of Academic Research in Progressive Education and Development, 7(4), 295-302.

Khairuldin, W. M. K. F. W., Embong, A. H., Anas, W. N. I. W. N., Ismail, D., \& Mokhtar, W. K. A.W. (2019). An Augmented Reality (AR) Approach in Educational Integration of Du'a in Islam. International Journal of Academic Research in Progressive Education and Development, 8(1), 32-39.

Khairuldin, W. M. K. F. W., Embong, A. H., \& Anas, W. N. I. W. N. (2019). Technological Approach in Education of Musafir (Muslim Traveler) in Islam: The Study on Mobile App Mysafar. International Journal of Academic Research in Progressive Education and Development, 8(1), 40-47.

Long, A.S. (2008). Sejarah falsafah edisi kedua. Bangi: Penerbit Universiti Kebangsaan Malaysia

Mastor, K.A. (2009). Etika ahli sains menurut pandangan Islam. Dlm. Mohd Yusof Othman (ed). Wacana sejarah dan falsafah sains: Sains dan masyarakat. Kuala Lumpur: Dewan Bahasa Dan Pustaka.

Mohamad Zain, S., Ismail, A.W. (1985). Pengenalan tamadun Islam dalam sains dan teknologi. Kuala Lumpur: Dewan Bahasa dan Pustaka.

Nasr, S.H (1986). Sains dan peradaban di dalam Islam. Bandung: Penerbit Pustaka.

Nasr, S.H. (2008). Islam dan sains moden. In Baharudin Ahmad (ed). Falsafah sains dari perspektif Islam. Kuala Lumpur: Dewan Bahasa dan Pustaka.

Othman, M.Y. (1996). Penerokaan al-Quran melalui sains. In. Mohd. Yusof Othman (ed). Siri Wacana Sejarah dan Falsafah Sains Jilid 5. Dewan Bahasa dan Pustaka: Kuala Lumpur

Sardar, Z. (1992). Hujah sains Islam. Terj. Abdul Latif Samian. Kuala Lumpur: Dewan Bahasa dan Pustaka

Shaikh Mohd Salleh. S.M.S \& Baharuddin, A. (t.t). Significance of science and scientific thought from the Islamic perspective. Centre of Quranic Research International Journal. 73-87 